3.

\title{
PRISTUPI JUŽNOSLAVENSKOM PITANJU \\ DR. ANTE TRUMBIĆA I BEOGRAD
}

\section{Stjepan Matković}

UDK: 32-05Trumbić, A.:327.39(=163)

Izvorni znanstveni članak

Sažetak: Autor analizira kako je Ante Trumbić, kao jedan od boraca za stvaranje jugoslavenske države tijekom Prvoga svjetskog rata, pristupao južnoslavenskom pitanju u duljem vremenskom razdoblju. Pri tome je osobito uzeo u obzir istraživačko pitanje o Trumbićevim odnosima s raznim predstavnicima iz Srbije, od državnika do niza drugih pojedinaca. U tekstu se autor bavi i epizodom oko sudbine Zadra nakon Prvoga svjetskog rata u kojoj se pojavljuje i otac Vladana Desnice.

Ključne riječi: južnoslavensko pitanje, jugoslavenstvo, Jugoslavenski odbor, hrvatsko-srpski odnosi

$\mathbb{0}$

z više-manje poznate historiografske naslove nastale u rasponu od 1920-ih godina do danas, glavni izvor za proučavanje ove intrigantne teme o južnoslavenskom pitanju u opusu Ante Trumbića njegove su političke bilješke, u kojima je s manjim ili većim vremenskim odmacima zapisivao brojne događaje, susrete, razgovore i obavijesti. One imaju i memoarske karakteristike jer ponekad donose retrospektivni osvrt, a uz njih se nalaze i brojni izvorni dokumenti. Sâm je Trumbić zapisao da je mnogo toga bilježio naprečac, da u njegovim rasutim zapisima ima delikatnih stvari, često i onih neprovjerenih i tek kad se one podvrgnu kritičkoj kontroli, moći će se „kasnije, recimo nakon 20 ili 30 godina kada u lič-

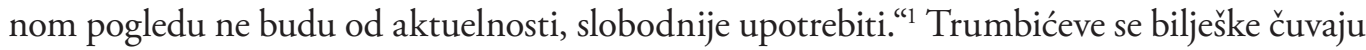
u današnjem Arhivu Hrvatske akademije znanosti i umjetnosti, gdje se nalaze od 1939., kad su ih njegovi prijatelji Ivan Meštrović i Pavle Ostović, neposredno nakon Trumbićeve smrti, predali upravi Jugoslavenske akademije znanosti i umjetnosti, a pomiješane su u priličnoj mjeri s opsežnom dokumentacijom Jugoslavenskog odbora te čine jednu cjelinu zajedno s njegovom, isto tako opsežnom, osobnom ostavštinom u splitskoj Sveučilišnoj knjižnici. ${ }^{2}$

$1 \quad$ Arhiv Hrvatske akademije znanosti i umjetnosti (dalje: Arhiv HAZU), fond Jugoslavenskog odbora (dalje: fond JO), Zaklada Jugoslavenskog odbora, bez sign.

2 O splitskom izvoru vidjeti: Dr. Ante Trumbić (1864. - 1938.). Životopis kroz spise osobnoga Arhiva u Sveučilišnoj knjižnici u Splitu (prir. Mihaela Kovačić i Marko Trogrlić), Split 2015. 
Tema o Trumbićevu pristupu južnoslavenskom pitanju kao jednome od oblika povezivanja južnih Slavena, koje je za njegova života imalo ključnu ulogu u političkim raspravljanjima, ima više poticaja: jedan je, primjerice, saglediv na tragu obilježavanja jubileja o Prvome svjetskom ratu u kojemu zapaženu ulogu ima Jugoslavenski odbor kao ključni predstavnik južnoslavenskog bloka političara s područja Austro-Ugarske, a drugi u prožimanju (dis)kontinuiranog odnosa prema jugoslavenstvu i koncepciji narodnog jedinstva kao nezaobilaznim temama vremena uoči, za vrijeme i poslije toga rata. U svakom pogledu, potpuno je jasno da je od početka 20. stoljeća do kraja Velikoga rata Trumbić iz svoje splitske sredine najprije započeo postupno zagovarati preobrazbu, a zatim sve otvorenije raspad Austro-Ugarske i pad habsburške dinastije, vidjevši u njoj glavnu smetnju za ostvarivanje političkog sustava bez podređenog položaja pojedinih naroda prema bečkoj i budimpeštanskoj vlasti. Pri tomu je važnu ulogu imala i procjena o neizbježnom sukobu dvaju velikih političkih saveza, koji je zbog svog značenja morao utjecati i na sudbinu manjih naroda. U prvom je razdoblju do Balkanskih ratova Trumbić nastojao poticati rješavanje otvorenih pitanja dogovorima s raznim predstavnicima koji su zagovarali unutarnju reformu Monarhije. Nakon neuspjeha na tom planu okrenuo se cjelovitom rješavanju južnoslavenskog pitanja mimo parlamentarnih metoda, smatrajući još prije izbijanja Prvoga svjetskog rata da ga treba poticati kroz međunarodnu politiku, suradnjom između svih čimbenika koji su po njemu predstavljali južnoslavensko područje i iskorištavanjem rata za izvedbu očekivanih promjena.

Uz primjetne intervale kao znakove vremena, pisalo se mnogo o Trumbiću, ponajprije kao o pioniru nove ere inaugurirane politikom „novog kursa“ na samome početku 20. stoljeća, kao i o jednome od nositelja prekretničkih poteza u političkom životu koji su bili označeni izbijanjem Prvoga svjetskog rata, promjenama na bojištima i ratnim ishodom. U tom je smislu riječ o značajnoj ličnosti po svojoj političko-diplomatskoj djelatnosti, modernoj i uglađenoj za svoje vrijeme, po nekima i liberalnoj i s razgranatom međunarodnom aktivnošću. Nesumnjivo je da se radilo o agilnom političaru koji je svojim potezima pridonio stvaranju prve jugoslavenske države izravnom akcijom traženja rješenja izvan sklopa Habsburške Monarhije. Na tom se putu zalagao i za suradnju sa srpskom stranom, vidjevši u njoj prirodnog saveznika za ostvarenje ranije iznesene misije. Taj zaokret za jednog izvorno pravaškog političara započeo je na prijelazu stoljeća, a dobio je zamah nakon dubokih promjena u 1903. godini, kad je kriza dualističkog sustava u Austro-Ugarskoj doživjela klimaks, a s druge je strane promjena dinastije u Beogradu otvorila drugačije perspektive „novog kursa“ pri pokretanju južnoslavenskog pitanja. Početno je pravaštvo na tom putu zabačeno, što i nije bila posebna specifičnost njegova razvoja jer je čitav niz pravaša iz toga razdoblja napuštao starčevićansku doktrinu i započeo zastupati drugačije političke koncepcije, a među kojima je osobito bila zamjetna i opcija jugoslavenskog integralizma. Prve podatke koji ukazuju na Trumbićev otklon od starčevićanske ideologije nalazimo u jednom novinskom članku u kojemu je „zagovarao izmirenje i najužu suradnju Hrvata i Srba da bi se ostvarila zajednica interesa jer susjedi ne mogu živjeti vječno u mržnji.“3 $U$ tom je kolo-

\footnotetext{
Riječ je o zapisu u splitskom Narodnom listu. V. Ante Smith Pavelić, Dr. Ante Trumbić, problemi hrvatsko-srpskih odnosa, München 1959., 15. Autor je ove knjige sin zubara Ante Pavelića, međuratni diplomat, a poslijeratni emigrant. I njegov je otac prešao put od frankovačkog pravaša do predsjednika jugoslavenskog Senata.
} 
pletu različitih protagonista i ideoloških evolucija postupno do izražaja došla ideja o ostvarivanju nacionalnog pitanja i drugačijeg tipa državne zajednice izvan habsburškog sklopa, uz prihvaćanje ustavnog monarhizma. U zadanoj konstelaciji odnosa takva je politička smjernica morala biti prikrivena i pažljivo izgrađivana, krenuvši najprije od unutarmonarhijskog pokušaja surađivanja protubečki nastrojenih političara različitih nacionalnosti, dakako, iz opozicijskih redova. Riječ je o političkoj praksi koja nije bila vezana samo uz južnoslavenski prostor Monarhije, nego se vidljivo zastupala i u primjeru njenih drugih naroda koji su smatrali da imaju drugorazredni status. Već se donošenjem Riječke i Zadarske rezolucije pogled ponovno koncentrirao prema oživljavanju ideologije narodnog jedinstva koja se promatrala, kako je to Miroslav Krleža zapisao imajući na umu Trumbića, „sa pogledom uperenim na daleke ciljeve", pri čemu je za njezina glavnog arhitekta pribilježio da je tada bio „uzvišen iznad svake političke stvarnosti“. ${ }^{4}$ Sljedeći korak koji je trebao osigurati relevantnost južnoslavenskog puta bilo je povezivanje s političkim predstavnicima iz Beograda. Riječ je o temi koja je u Trumbićevu slučaju slabo pokrivena izvorima. Za razliku od brojnih drugih političara koji su od 1903. nadalje posjećivali glavni grad Srbije, nema obavijesti da je i on onamo odlazio za „austrougarsko" vrijeme. Neposredno uoči početka Velikog rata Trumbić je u svojim autobiografskim bilješkama lapidarno iznio podatak o više susreta koje je imao s Jovanom Jovanovićem, srpskim poslanikom u Beču, čime je ukazao na veze sa službenim predstavnicima Kraljevine Srbije. ${ }^{5}$ Nisu poznati detalji razgovora, no iz raznih historiografskih nalaza dobiva se jasna slika o političkoj orijentaciji. Za vrijeme Balkanskih ratova u Trumbića je primjetna srbofilska orijentacija, koja se tumačila i kao anticipacija austrougarske sudbine po uzoru na Osmansko Carstvo. ${ }^{6}$ Prema dostupnim materijalima, vrlo je vjerojatno da je glavni posrednik između njega i Vlade u Beogradu bio Nikola Stojanović. U jednome pismu koje je uputio Supilu na početku rata Trumbić je napisao:

Kako vidiš, ova misao posmatra našu narodnu stvar s općeg gledišta i isključuje partikularistične osnove o stvaranju grupa u uskom smislu hrvatskih ili srbijanskih aspiracija. Dobro je da su Bošnjaci s nami složni. Pred godinu dana bio je ovaj Stojanović s nekim drugim svojim sumišljenicima kod mene u Splitu, da izmijenimo mnijenja te smo već tada bili podpuno složni u ovakovom shvaćanju naše budućnosti tako da je o tome razgovoru izvijestio sada u Nišu i došao ovamo e da nastavimo gdje smo onda bili stali. ${ }^{7}$

Izvjesno je da su između Stojanovića, koji je prije rata bio član Bosansko-hercegovačkog sabora i odvjetnik u Tuzli, i Trumbića uspostavljeni odnosi za vrijeme Balkanskih ratova. Oni su se susreli u Splitu i razgovarali o političkoj situaciji. Prema Stojanoviću, zaključili su da bi se u slučaju objave rata Austro-Ugarske Srbiji bilo potpuno otvorilo južnoslavensko pitanje. ${ }^{8} \mathrm{~S}$ obzirom na to da južnoslavenski zagovornici borbe protiv Monarhije nisu bili

\footnotetext{
Miroslav KrLeŽA, Marginalije (prir. Vlaho Bogišić), Beograd 2011., 486.

Ivo Petrinović, Ante Trumbić. Politička shvaćanja i djelovanja, Zagreb 1986., 110.

6 Ivo Perić, Ante Trumbić na dalmatinskom političkom poprištu, Split 1984., 136-137.

Arhiv HAZU, fond JO, kut. 51, dok. br. 87, Rim, 9. 11. 1914.

8 Nikola Stojanović, Mladost jednog pokolenja (uspomene 1880-1920) (prir. Mile Stanić), Beograd 2015., 137-138. Stojanović u svojim uspomenama sastanak pogrešno datira u 1912., a neki drugi povjesničari u 1913. (v. I. PetriNović, Ante Trumbić, 111), što se podudara s Trumbićevim navodom u spomenutom pismu, ali is jednom studijom samog Stojanovića, koji navodi susret iz siječnja 1913. V. N. STOJANović: Jugoslovenski odbor (Članci i dokumenti), Zagreb 1927., 9.
} 
naoružani, što bi im omogućilo neki oblik aktivnog otpora, obojica su se dogovorila kako je najvažnije da viđeniji političari odu u emigraciju i rade na internacionalizaciji južnoslavenskog pitanja te započnu obračun s Austro-Ugarskom. Taj je dogovor proveden te su se obojica ponovno susrela u Italiji neposredno nakon početka rata, pri čemu je Stojanović najprije prebjegao u Srbiju i uskoro postao predstavnik srpske Vlade, slijedeći prema vlastitom svjedočanstvu Pašićeve instrukcije, a Trumbić je nakon propitivanja saveznika krenuo u izgrađivanje emigrantske organizacije.

Trumbićevi biografi i istraživači jugoslavenskog puta sigurni su da je on uoči Sarajevskog atentata pristao na opciju da Srbija „preuzme ulogu jugoslavenskog Pijemonta“? Prema tomu, odlazak u inozemstvo i rad na stvaranju Jugoslavenskog odbora bio je nastavak djelovanja u tom pravcu. Sve do stvaranja emigrantske organizacije Trumbić je u Italiji sa suradnicima neprijeporno promatrao zbivanja u Srbiji, koja je od početka rata bila zahvaćena ratnim događanjima, pozorno pratio obranu Beogradu od napada austrougarske vojske i sa zadovoljstvom dočekao odluke srpske Narodne skupštine u Nišu o ratnim ciljevima. Jedan od glavnih informatora o zbivanjima u Srbiji bio mu je Robert W. Seaton-Watson, koji ga je nakon posjeta Beogradu i Nišu uvjeravao u dobre ishode ,jugoslavenskog stanovišta“. Istovremeno je održavao kontakte s Ljubom Mihajlovićem, srpskim poslanikom u Rimu, $s$ kojim je nastojao kristalizirati južnoslavensko pitanje, i to ponajprije u kontekstu odnosa službene Srbije prema talijanskim aspiracijama prema istočnojadranskoj obali i stvaranja organizacije južnoslavenskih emigranata. Prve je pobjede srpske vojske Trumbić euforično komentirao u jednom pismu Supilu: „Ovim djelom Srbija se povratila u Evropu i zauzela u Evropskoj familiji svoje mjesto priznanjem sviju. "11

U tim prvim političkim koracima prema organizaciji emigrantske organizacije Trumbić nije imao, kao i prije rata, previše afiniteta ni prema kulturnoj politici, pa ni beletrističkih ambicija. Kao vrlo bliski prijatelj već međunarodno priznatnog umjetnika Ivana Meštrovića, još jednog člana Jugoslavenskog odbora i predratnog javnog radnika, bio je upućen i u tu problematiku, koja je naročito tijekom boravka u inozemstvu imala svoju izraženu propagandnu zadaću u britanskoj javnosti, pa i u nekim prekooceanskim zemljama. Nakon pobjeda srpske vojske nad austrougarskom, Trumbić je najavljivao i pobjede na kulturnom području kad „naš Ivan [Meštrović] u liku Kraljevića Marka odjezdi na Šarcu u London da posvjedoči kulturnu sposobnost našega naroda. ${ }^{\text {12 }} \mathrm{O}$ tome još, primjerice, svjedoči i Appeal of the Yugoslav Artists, u kojemu je niz književnika i umjetnika tražio savezničku potporu, pozivajući se pri tome i na primjer talijanskog ujedinjavanja pod Mazzinijem i Garibaldijem, kao i na pijemontsku ulogu Srbije, ali tražeći istodobno da Italija kao simbol nacionalne borbe prizna pravo naroda na samoodređenje. ${ }^{13} \mathrm{~A}$ bila je riječ o javnosti koja je

\footnotetext{
9 I. Petrinović, Ante Trumbić, 111; A. Smith Pavelić, Dr. Ante Trumbić, 29; Dragovan Šepić, Italija, Saveznici $i$ jugoslavensko pitanje, Zagreb 1970., 20.

10 „Trumbićev 'dnevnik'“, Historijski pregled, 2/1959., 186.

11 Arhiv HAZU, fond JO, kut. 51, dok. br. 91, Rim, 17. 12. 1914.

12 Isto.

13 Arhiv HAZU, fond JO, kut. 140, dok. br. 13, bez datuma. Među potpisnicima bili su: Ivan Meštrović, Jovan Dučić, Tomo Rosandić, Risto Stijović, Đorđe Jovanović, Slavko Vorkapić, Jozo Kljaković, Josip Kosor i dr.
} 
bila gotovo potpuno novi svijet za južnoslavenske agitatore s prostora Austro-Ugarske. Ne treba smetnuti s uma da je Trumbić, zajedno s Meštrovićem, tijekom ratnih londonskih dana surađivao i s Milanom Ćurčinom, koji je u srpskom poslanstvu bio zadužen za propagandnu djelatnost, a ta će suradnja imati svoj nastavak i na početku Kraljevstva SHS-a. ${ }^{14}$

U historiografiji se najviše propitivao Trumbićev odnos prema Nikoli Pašiću, i to na temelju analize djelovanja dvojice ratnih saveznika s različitim statusima i viđenjima rješavanja nacionalnog pitanja, pri čemu je naročito pritisak sadržaja Londonskog ugovora zbog svoje prijetnje korjenitom dezintegracijom Hrvata diktirao uvjete i intenzitete njihove kooperacije, a važan utjecaj imali su i drugi prekretnički događaji poput vojnog zauzimanja Srbije prodorima udruženih snaga Centralnih sila, revolucije u Rusiji ili ulaska Sjedinjenih Američkih Država u rat, kojima je južnoslavensko pitanje stupilo u novu fazu razvoja. ${ }^{15}$ Međutim, opseg Trumbićeve suradnje sa srpskim predstavnicima bio je znatno veći, bilo da je riječ o suradnicima ili sugovornicima. Iz arhiva Jugoslavenskog odbora intenzitet odnosa pokazuju razmjene pisama s Božom Markovićem, Milanom Ćurčinom, Stevanom K. Pavlovićem, Bogdanom Popovićem, Milanom Grolom i mnogim drugim pripadnicima srpskih službi, naročito onima iz redova srpske diplomacije. Uz to, svoje mjesto zauzimali su i odnosi prema Srbima iz Austro-Ugarske, koji su sudjelovali u radu Jugoslavenskog odbora ili su na neki način bili pod radarom te organizacije. Premda su prijepori s Pašićem bili gotovo stalni i neprikriveni, oni ipak nisu utjecali na odustajanje od ideje ujedinjavanja Hrvata i Srba oko jugoslavenskog imena. Bez znakova skretanja sa zacrtanog puta, kao u slučaju Frana Supila, ustrajni Trumbić polagao je glavne nade u propadanje Austro-Ugarske i stvaranje zajedničke južnoslavenske države. Pri tome nije bilo riječi o samostalnoj hrvatskoj državi kao povratku na pravaške ili neke pozicije poput prijedloga o formiranju slovensko-hrvatske države kao alternative pašićevskoj orijentaciji, bez obzira na to što su pojedini impulsi dolazili sa strane savezničke diplomacije. Upravo isticanjem integralnih južnoslavenskih interesa njemu je uspijevalo pridobivati pozornost Saveznika, poglavito onih s britanske strane koji su u neposrednoj budućnosti vidjeli mjesto za jednu potpuno novu državu u „novoj Evropi“. U kontekstu suradnje sa srpskom stranom upada u oči još jedan detalj. To je težnja za suradnjom sa srpskom opozicijom koja bi u odnosima s Jugoslavenskim odborom prepoznala obostranu vrijednost u promicanju jugoslavenske ideje. Za vrijeme rata do izražaja je tako došla suradnja s Ljubom Davidovićem, koji je tijekom razilaženja između predsjednika Jugoslavenskog odbora i Pašića poticao na obostrane dogovore i time omogućio Trumbiću pripremanje terena za prihvaćanje Krfske deklaracije. ${ }^{16}$ $\mathrm{Na}$ kraju rata Trumbić je pojačao svoju ranije uspostavljenu vezu is Božom Markovićem, predratnim urednikom Slovenskog Juga, tada sa sjedištem u Ženevi, gdje je vodio ured srp-

14 Stjepan Matкović, „Milan Ćurčin, Južnoslavensko pitanje u Prvome svjetskom ratu i rasprave o Sarajevskom atentatu“, Istorijski zapisi, 87/2014., br. 3-4, 115-133.

15 O tome srazu, koji je simbolizirao i sukob dvaju različitih pristupa južnoslavenskom pitanju i stvaranju jugoslavenske države, objavio je u novije vrijeme knjigu Dejan Djokić pod naslovom Nikola Pašić and Ante Trumbić. The Kingdom of Serbs, Croats and Slovenes, London 2010. O Pašiću kao branitelju srpskih interesa v. i monografske radove Đorđa Stankovića: Nikola Pašić i Hrvati (1918-1923), Beograd 1995.; Srbija i stvaranje Jugoslavije, Beograd 2009.

16 Božidar Marković, „Prvi koraci ka narodnom sporazumu“, Spomenica Ljubomira Davidovića, bez god., 56-58. 
skog Presbiroa. Njemu je Trumbić 1918. - očito misleći da ga može udaljiti od Pašićeve pozicije i približiti svojim pogledima koje je razvijao u Jugoslavenskom odboru - razlagao da se „ne smije organizacija stvarati na bazi plemenskoj ni vjerskoj. ${ }^{\text {“17 }}$ Štoviše, predsjednik Jugoslavenskog odbora pisao mu je: „Treba isticati jugoslavenstvo, Jugoslaviju, kao obilježje cjeline narodne i državne, ali tako da se ovi nazivi ne dovode u imkompatibilitet sa narodnim imenima. ${ }^{\text {"18 }}$ Iz toga se vidi politička odlučnost da se na srpskoj strani traže suradnici oko načina južnoslavenskog ujedinjavanja koji bi bili spremni odstupiti od stajališta pašićevske Vlade. Jedan od bezuspješnih poteza bio je i u pokušaju osnivanja Jugoslovenske demokratske lige u studenome 1918. s programom za „čitav troimeni narod“. I na toj ideji suprotstavljanja Pašićevu režimu koji je mogao „da unese haos i u unutrašnju politiku Jugoslavije" bili su okupljeni Trumbić, Marković, Grol i Stojanović, a trebao ih je sve okupiti Jovan Cvijici. ${ }^{19}$ Tom je prigodom Trumbić pisao istaknutom prvaku hrvatskih liberala i nekadašnjem članu Hrvatsko-srpske koalicije Ivanu Lorkoviću o svom viđenju tog programa:

Jedan narod, jedna država osnovana na demokratskim principima slobode i jednakosti. To je za nas aksiom, sve je ostalo za diskusiju. $S$ toga stajališta treba suzbijati svjesno i energično sve tendencije koje idu za partikularizmom plemenskim, kao i one koje teže za namećanjem jednoga plemena drugomu, jedne klase drugoj itd. U našem narodu nema jedne zemlje, ili jedne klase, koja bi mogla svojim superiornim razvitkom biti učiteljem i uzorom drugima. Naše jedinstvo mora da bude sinteza narodne cjeline, u kojoj ima da se fuzioniše sve dosadašnje narodne tekovine i osebine. Stoga Jugoslavija nije ni srpstvo, ni hrvatstvo, ni slovenaštvo, nego demokratsko stapanje partikularnih plemenskih djelova u jednu narodnu cjelinu. ${ }^{20}$

Tako je u prvim danima Kraljevstva SHS Trumbić odredio svoj stav o državi i naciji.

Sljedeću stranicu otvorila je situacija nakon 1918., kad je Austro-Ugarska već postala stvar prošlosti, a pokušaji habsburške restauracije nisu nailazili na plodno tlo. Pred novom jugoslavenskom državom nalazio se niz izazova. Trumbićev izbor za prvoga ministra vanjskih poslova vezao ga je uz diplomatsku arenu na Versailleskoj mirovnoj konferenciji i nastupe na međunarodnim forumima. Sve do kraja rada Konferencije nije dolazio u Beograd. ${ }^{21}$ Zbog toga nije ni mogao doživjeti kako je prijestolnica započela mijenjati svoju fizionomiju postavši središtem Srba, Hrvata i Slovenaca. No, izbor za ministra nije prošao posve glatko. Trumbić se žalio da ga se nije na vrijeme obavijestilo o svom postavljanju na ministarsko mjesto, ali i da su se u tom resoru počeli provoditi neki potezi bez njegova znanja. Da stvari u Ministarstvu nisu dobro funkcionirale, pokazuje i pismo Stevana K. Pavlovića u kojemu je Trumbiću javljao o sramnoj krizi u državi koja je bila pitanje „izvoza i eventualne zarade pojedinaca“, o svađama i o tome da je u „Ministarstvu pravi haos pa

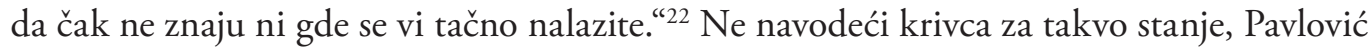
je zabilježio da se u Beogradu „nadaju dolasku svog ministra“, koji je svojim autoritetom

\footnotetext{
17 Arhiv HAZU, fond JO, kut. 8, bez sign.

18 Isto.

19 Arhiv HAZU, fond JO, kut. 8, br. dok. 6, Marković - Trumbiću, Ženeva, 24. 12. 1918.

20 Arhiv HAZU, fond JO, kut. 40, dok. br. 42, Pariz, 24. 12. 1918., 3.

21 Đ. StankoviĆ, Srbija i stvaranje Jugoslavije, 247.

22 Arhiv HAZU, fond JO, kut. 145, dok. br. 45, Pariz, 17. 8. 1920.
} 
trebao konsolidirati diplomatski resor. $S$ druge strane, utjecajni diplomat, srpski poslanik u Parizu i član Mirovne konferencije Milenko Vesnić smatrao je da Trumbić nije bio lojalan u suradnji s predstavnicima iz Srbije pa je uputio i protestna pisma Ministarstvu vanjskih poslova protiv njegova ministra. ${ }^{23}$ I ovdje je do izražaja došao sukob mišljenja o uređenju i vođenju Kraljevine SHS, pri čemu je Vesnić polazio od stajališta da Srbija mora biti nositeljica središnje uloge u novoj državi. Kasnije, nakon izlaska iz Vlade, Trumbić će zagovarati snažniji utjecaj Narodne skupštine na vanjsku politiku. Iz njegovih političkih bilježaka vidi se da je često dobivao informacije o atmosferi u Beogradu od svojih dalmatinskih prijatelja koji su i dalje imali političku težinu jer su predstavljali svoja područja u novome glavnom gradu. No, ovdje se već uočavaju obrisi budućih sukoba. Na primjer, Mate Drinković obavještavao ga je o vojničkom pitanju i skrenuo mu pozornost na to da će odluke beogradske Vlade izazvati nezadovoljstvo. Od oficira bivše austrougarske vojske zahtijevalo se da posebnim molbama zatraže prijam u vojsku. $S$ druge strane, Ante Biankini opisao mu je 1920. na sljedeći način situaciju u državnom središtu: „U Beogradu hoće da te prikažu za republikanca. ${ }^{\text {"24 }}$ Riječ je bila o glasinama da su postojale neke Trumbićeve starije depeše u kojima se on protivio da srpska vojska („srpske trupe“) sudjeluje u zauzimanju Hrvatske nakon austrougarskog sloma i da tu ulogu preuzmu vojne snage savezničkih velesila. Iz toga se izvodio zaključak da je postojalo međusobno nepovjerenje koje se moglo samo zaoštriti zbog osporavanja krune.

Nakon osnivanja Kraljevstva SHS, iz Beograda mu se javio stari poznanik Ćurčin, koji ga je pozvao da se priključi skupini osnivača časopisa Nova Evropa. Riječ je o periodici koja je započela izlaziti u Zagrebu, s uredničkom politikom jugoslavenske integralističke orijentacije i tendencije što šireg okupljanja suradnika oko takve ideje prožete afirmacijom načela demokratizma i građanskog nacionalizma. ${ }^{25} \mathrm{U}$ pismu koje mu je uputio 1920 . Ćurčin je podsjetio na njihov raniji susret u Parizu i izrazio uvjerenjenje „da nema smetnje da podjete s nama." ${ }^{26}$ U vezi s takvom orijentacijom i temom koja se pojavila u Novoj Evropi u pogledu Solunskog procesa treba se podsjetiti i da je Trumbić za vrijeme Prvoga svjetskog rata, pa i kasnije u svojim privatnim bilješkama na više mjesta pokazivao sklonost prema pukovniku Dragutinu Dimitrijeviću Apisu, smatrajući da je riječ o žrtvi političkog procesa. Stoga se još za boravka na Krfu zalagao za amnestiju ili smanjivanje kazne optuženicima tog procesa jer je držao da je riječ o popularnim oficirima koji su imali određene zasluge za širenje jugoslavenskog patriotizma. ${ }^{27}$ Taj slučaj ukazivao je na dodatne prijepore prema Pašiću, ali je dovodio u sumnju i ispravnost držanja regenta Aleksandra, što je bila još jedna tema u raspravljanju o suštini jugoslavenstva koja će se nastaviti u međuratnom razdoblju.

Konačno, ova tema ima i poneku, vrlo tanku, sponu s obitelji Desnica, i to s Vladanovim ocem Urošom, što se vidi i po predstavci zadarskih uglednika koja je Trumbiću bila izrav-

23 Radoslav Vesnić MlaĐi, Dr Milenko Vesnić gransenjer srpske diplomatije, Beograd 2008., 450-451.

24 Arhiv HAZU, fond JO, kut. 154, dok. br. 45, 24. 5. 1920.

25 Drago Roksandić, Srpska i hrvatska povijest i „nova historija“, Zagreb 1991., 243. Šire interpretacije tog časopisa v. u zborniku radova: Nova Evropa 1920-1941 (ur. Marko Nedić i Vesna Matović), Beograd 2010.

26 Arhiv HAZU, fond JO, kut. 40, Ćurčin - Trumbiću, 15. 3. 1920.

27 Arhiv HAZU, fond JO, kut. 128, dossier Dimitrijević Dragutin i drug.; A. Smith Pavelić, Dr. Ante Trumbić, 94; Dragoslav Janković, „Ante Trumbić na Krfskoj konferenciji“, Život i djelo Ante Trumbića (ur. Ljubo Boban i Ivan Jelić), Zagreb 1991., 64. 
no upućena kao ministru vanjskih poslova i članu jugoslavenske delegacije na Mirovnoj konferenciji u Parizu radi inzistiranja na gorljivijoj borbi za uklanjanje talijanske okupacije i povratak Zadra u okrilje Dalmacije u novom poslijeratnom poretku. ${ }^{28} \mathrm{Za}$ sada nam još nisu poznati detalji o mogućoj, intenzivnijoj suradnji u ranijem razdoblju, posebice u vremenu uspjeha politike „novog kursa“, kad je Uroš Desnica stavio svoj potpis na Zadarsku rezoluciju i bio članom odbora za dogovaranje s vodećom strankom dalmatinskih Hrvata. Zasigurno je, prema pisanju suvremenih povjesničara, Desnica pripadao krugu najvažnijih političkih sudionika koji su stajali iza „,novog doba“ $i$ isticali svoja integralistička nagnuća izražena u misli da su Srbi i Hrvati jedan narod. ${ }^{29}$ Trumbić je tada podržavao takvu orijentaciju hrvatsko-srpskog sporazuma, vidjevši u njoj temelj za jačanje statusa Dalmacije, ali i podlogu za njeno ujedinjavanje s Banskom Hrvatskom. No, neki su povjesničari već zamijetili da se nakon javnog približavanja i praktične strane suradnje hrvatske i srpske strane u Dalmaciji ipak i dalje radilo o tome da su svi dionici zadržavali „svoje težnje“, stoga je razrješavanje južnoslavenskog pitanja u znatnoj mjeri ovisilo o nizu različitih faktora. ${ }^{30}$ Nakon okončanja rata započela je borba za priznavanje nove države i određivanje međudržavnih granica. U kolopletu događaja vezanih uz talijansko zauzimanje istočnojadranske obale, poslanik u Rimu Antonijević obavijestio je ministra Trumbića o interniranim osobama iz Dalmacije i Istre, kojih je - prema njegovoj procjeni - bilo između tri i četiri tisuće. ${ }^{31} \mathrm{Na}$ popisu interniraca u Sardiniji našao se i Uroš Desnica. Antonijević je iznio dojam da su talijanske okupacijske vlasti internirale „sve što je najbolje“, kako bi u zaposjednutim krajevima narod ostao „potpuno obezglavljen“. No, veza između Trumbića i Desnice poprima znakove nepovjerenja u kontekstu diplomatske borbe. Poslijeratni tekst predstavke uglednika u Zadru bio je zapravo pomalo očajnički apel jugoslavenskoj delegaciji da nipošto ne zapostavi Zadar u diplomatskim raspravama i ne prizna u njegovu slučaju prednost talijanskoj strani. Bio je potkrijepljen brojidbenim pokazateljima o prednosti, kako dokument bilježi Jugoslavena, odnosno stanovništvo hrvatskog ili srpskog jezika, kao i dijecezanskog sjedišta. Trumbić je doista prije zaključivanja Rapallskog ugovora i uz pritiske velikih savezničkih sila odlučio da u pregovorima od Zadra „ne pravi pitanje, pogotovo što je od Talijana dobio ustupak u pogledu luke Bakar koja je pripala Kraljevini SHS i što je za Rijeku osigurao položaj slobodnog grada. “32 Tako je svojim postupkom mogao stvoriti nezadovoljstvo u onih stanovnika Dalmacije koji su sve više gubili nadu da će ući u jugoslavenski sklop. Iz pisma koje je Gajo Bulat uputio Trumbiću početkom 1921. dobiva se već pouzdaniji podatak o nepovjerenju. Bulat je, pišući iz Splita, dakle s terena, svom predratnom sugrađaninu i suradniku iz političko-stranačkog života najprije javio da se kraljeva („,centralna“)

\footnotetext{
28 Arhiv HAZU, fond JO, kut. 128, bez sign., 26. 2. 1920.; među potpisnicima bili su, uz Desnicu, još i: Vicko Ivčević, Josip Tončić, Stevo Metličić, Jakov Čuka, Jerko Machiedo, Milorad Medini, Marko Ježina i jedan potpisnik s nečitkim prezimenom.

29 D. Roksandić, „Dr. Uroš Desnica 1918.-1921.: životopisne nedoumice na raskrižju epohâ“, Spalatumque dedit ortum. Zbornik povodom desete godišnjice Odsjeka za povijest Filozofskog fakulteta u Splitu (ur. Ivan Basić i Marko Rimac), Split 2014., 502.

30 Tereza Ganza-Aras, Politika „novog kursa“ dalmatinskih pravaša oko Supila i Trumbića, Split 1992., 336.

31 Arhiv HAZU, fond JO, kut. 45, dok. br. 243, Rim, 14. 5. 1919.

32 A. Smith Pavelić, Dr. Ante Trumbić, 274.
} 
Vlada nije još uvijek konzultirala s dalmatinskom pokrajinskom Vladom o komisiji za uređenje granice Zadra, a onda u sljedećoj rečenici prenosi Desničino mišljenje da je zapravo Trumbić nastojao zadržati potpuni nadzor nad radom pograničnih komisija. ${ }^{33} \mathrm{Ne}$ znamo je li Trumbić odgovorio Bulatu, no, prema svemu sudeći, problem je bio nešto širi jer je bio posljedica dubljih preslagivanja u dramatičnim okolnostima raspada starog imperija, talijanske okupacije i izgrađivanja nove vlasti u drugim dijelovima Dalmacije. O tome piše i Josip Smodlaka u svojoj biografiji, kad bilježi da su talijansko zauzeće Zadra i postanak Splita novim središtem dalmatinske uprave izazivali trzavice. ${ }^{34}$ Između ostalog, došlo je i do protesta Srba iz sjeverne Dalmacije koji su tražili da netko od njih uđe u sastav zemaljske privremene Vlade i tada Desnica biva imenovan njezinim povjerenikom. ${ }^{35}$

Trumbićev odlazak s ministarskog mjesta i premještanje u opozicijske redove doveli su do pogoršanja odnosa za koje možemo zaključiti da je značilo podizanje barikada. No, nužno je dodati jednu napomenu. Za razliku od odnosa u Dalmaciji, gdje je nakon Rapallskog sporazuma došlo do smirivanja tenzija izazvanih strahom od uspostave granica slijedom odredbi Londonskog ugovora, a shodno tomu i do prestrukturiranja političkostranačke scene, komunikacijski kanali s Beogradom nisu bili zatvoreni. Unatoč sve višim preprekama, i dalje se odvijala razmjena mišljenja s pojedinim beogradskim političarima, što je značilo opipavanje odnosa snaga i provjere raspoloženja. ${ }^{36}$ Sve u svemu, Trumbić se priklonio federalistički orijentiranoj Hrvatskoj zajednici, a Desnica je još prije toga pristupio Narodnoj radikalnoj stranci u Splitu. Prvi se tako našao u opozicijskim redovima, i to ne samo na razini čitave države, nego i među hrvatskim strankama jer su na toj strani glavnu riječ preuzeli Stjepan Radić i njegovo okruženje s kojim su predstavnici tzv. građanskih stranaka, slabo naviknuti na pučku agitaciju, teško ostvarivali suradnju, a drugi je bio u boljem položaju oslonca na vladajuću stranku koja je tada i u raznim područjima Dalmacije nastojala izgraditi solidno uporište. Uz to, Trumbić se 1923. preselio u Zagreb, gdje je otvorio svoj odvjetnički ured. Glavna točka prijepora postao je Trumbićev sada već neprijeporni zaokret prema republikanstvu, a takvo udaljavanje od krune označavalo se opasnošću za čitavu državu koja se još nije konsolidirala. ${ }^{37}$ Trumbić u svojoj novoj ulozi nije odbacio suradnju sa srpskom stranom, čime je pokazao da za njega i dalje postoji jugoslavenski prostor djelovanja. No, prema njemu je u novim okolnostima trebalo doći do ozbiljnijeg zaokreta koji se mogao postići samo ako narod „kaže još jednu veliku riječ““ ${ }^{38}$ Drugim riječima, to je bio napad na politički sustav centralizma u kojemu je Beograd, po njemu,

33 Arhiv HAZU, fond JO, kut. 45, Split, 10. 2. 1921

34 Zapisi Dra Josipa Smodlake (ur. Marko Kostrenčić), Zagreb 1972., 58.

35 Prema izvještaju Agence Yougoslave iz Ženeve od 14. 11. 1918., koji se čuva u Arhivu HAZU, JO, kut. 11, i splitskom Novom dobu od 5. 11. 1918., Desnica je 2. studenoga postao zamjenikom provizorne Vlade u Dalmaciji, a tu je Vladu imenovalo Narodno vijeće SHS u Zagrebu.

36 V. primjer razgovora između Trumbića i radikala Miše Trifunovića koji se problematizirao kao dio onomadnih političkih kombinatorika, u: Đ. STANKović, Nikola Pašić i Hrvati, 237-238.

37 O tipičnoj kritici dalmatinskih radikala v. Lujo Baкотіć, „Dr. Ante Trumbić“, Država (Split), 18. 12. 1924., 1; Marijan Buljan, „Uroš Desnica i Narodna radikalna stranka u Splitu 1920-ih prema splitskoj periodici“, Vladan Desnica i Split 1920.-1945. Zbornik radovas Desničinih susreta 2014. (ur. Drago Roksandić i Ivana Cvijović Javorina), Zagreb 2015., 290.

38 „Dr. Ante Trumbić o Krfskoj deklaraciji“, Hrvatska riječ (Split), br. 184, 1924., 3. 
postao simbol vlastodržaca koji ponižavaju narod. U toj je javnoj kritici Trumbić istaknuo upravo primjer Ministarstva vanjskih poslova koje je prozvao za lošu diplomatsku službu i krnjenje državnih interesa. ${ }^{39}$ Kasnije još u Trumbića nalazimo spominjanje Uroša Desnice u sažetoj zabilješci iz 1930., u kojoj ga apostrofira u kontekstu djelovanja bivše radikalske skupine u Splitu, koja je u novim okolnostima nastojala biti jednim od mjesnih oslonaca Vlade generala Petra Živkovića, i to uz izvjesne uspjehe jer je na dočeku „bilo naroda“, što bi se moglo protumačiti tako da je režim tada mogao računati na određenu potporu. ${ }^{40}$ Drugi je primjer iz 1933., kad Trumbić opisuje dolazak Nike Novakovića Longa iz Knina i zatim ga komentira kao akciju opozicionara koji je nastupao protiv svojih protivnika iz vladajućih redova s terena, kao što su senator Desnica i Nikola Subotić. U ovom drugom primjeru evidentno je da Trumbić sagledava takva politička kretanja kroz prizmu umanjenog utjecaja nekadašnjih radikala.

Ostalo je manje istraženo, ali svakako ne i prešućeno ili prikriveno kako je Trumbić prolazio kroz više životnih etapa u širokom vremenskom rasponu od 1890-ih do 1938. i postupno produbljivanjem krize u prvoj Jugoslaviji sve manje vjerovao u njenu stabilnost. ${ }^{41}$ Može se čak i tvrditi, paradoksalno u odnosu na njegovu raniju misiju, da je uspostavio veze i s krugovima političke emigracije, ali ovoga puta jasne protujugoslavenske orijentacije poput bivših habsburških oficira koji su odmah nakon Prvoga svjetskog rata nastavili živjeti po raznim gradovima Austrije (S. Sarkotić, I. Perčević, S. Duić) ili pojedinih pripadnika ustaškog pokreta (A. Pavelić, M. Budak, M. Lorković, E. Bulat) koje je otprije poznavao iz vremena suradnje u političkom sustavu Kraljevine SHS ili je, pak, bila riječ o sinovima očeva bliskih jugoslavenskih orijentaciji s kojima je radio na zajedničkim projektima još u austrougarskom razdoblju, što je bilo dramatično svjedočanstvo o njegovoj dubokoj razočaranosti državom za koju se tijekom Velikog rata otvoreno borio, a pouzdano se može reći da je bio jednim od njenih sutvoraca. ${ }^{42}$ Do prelamanja Trumbićevih odnosa prema središtu države nepobitno dolazi nakon skupštinskog atentata u Beogradu i skorog proglašenja šestosiječanjske diktature. Radikalne promjene i permanente krize u potpunosti su dovele do gubitka povjerenja u staru jugoslavensku ideju. Od početka 1930-ih Trumbić se sve više povezivao s novim vodstvom Hrvatske seljačke stranke koje je preuzelo kormilo njene uprave nakon smrti Stjepana Radića. U tim okolnostima, što je represija režima bila snažnija, to je bilo i veće ogorčenje nekadašnjih zagovornika jugoslavenstva koji su se našli u opoziciji. Trumbić je bio i jedan od odvjetnika u prvom procesu protiv Mačeka i niza drugih manje poznatih optuženika, mahom omladinaca optuženih za pokušaje izvođenja terorističkih akcija, iz prve polovine 1930., koji se u Beogradu vodio pred Državnim sudom za zaštitu države. ${ }^{43}$ Riječ je o Sudu osnovanom krajem 1929. godine radi zaštite javnog po-

\footnotetext{
39 „Prilike u našoj diplomatskoj službi. Nedovoljno učešće Hrvata i Slovenaca“, Novo doba (Split), br. 298, 1927., 2. U toj prigodi Trumbić tvrdi: „Diplomatsku službu drže u Beogradu za sebe kao svoj monopol.“

40 Arhiv HAZU, fond A. Trumbić, kut. 314, bez sign., spis s datumom 29. 8. 1930.

41 Ljubo Boban, „Prilozi za biografiju Ante Trumbića u vrijeme šestojanuarskog režima,1929-1935“, Historijski zbornik, 21-22/1968. - 1969., 1-73.

42 Arhiv HAZU, fond JO, svežanj 126, sign. 126/49.

43 Dragoljub Jovanović bilježi da su Beograđani mogli vidjeti Trumbića, nakon njegova prekinutog govora u Ustavotvornoj skupštini, tek 1930. i 1933., kad je nastupao kao odvjetnik na Državnom sudu. Dragoljub Jovanović, Ljudi, ljudi, knj. II, Beograd 1975., 80.
} 
retka i sigurnosti. Presudom toga Suda Maček je bio oslobođen tereta krivnje, no veći dio mladih okrivljenika osuđen je u rasponu od petnaestogodišnje do kazne od šest mjeseci strogog zatvora. U svojim političkim bilješkama Trumbić je dosta pisao o pojedincima koji su u beogradskom zatvoru Okružnog suda posjećivali Mačeka i uglavnom izvještavali o korektnom odnosu zatvorske uprave i čuvara prema predsjedniku HSS-a. Trumbić, pak, o svom boravku u Beogradu i nastupu na Sudu nije ostavio zapisa. Istodobno nije imao riječi odobravanja za pokušaje pojedinih hrvatskih javnih radnika, poput Svetozara Rittiga ili Milivoja Dežmana, koji su odlazili kralju u Beograd i time se opredijelili za režim diktature. Deputacije su za njega bile promašene jer njeni članovi nisu imali nikakvu javnu potporu. Riječi hvale nije imao ni za hrvatske ministre u kraljevoj Vladi. ${ }^{44}$ Konačno, Trumbić se udaljio i od nekadašnjih sugovornika iz redova Demokratske stranke, koji su mu se očito zamjerili zbog njihove osude Zagrebačkih punktacija koje je osobno stilizirao. Za Ljubu Davidovića i njegovo okruženje tvrdio je da žele samo sudjelovati u Vladi, a da im interesi hrvatske strane nisu predmet rasprave jer ne žele zagovarati novo uređenje države. ${ }^{45} \mathrm{Iz}$ te je tvrdnje zaključio da u Srbiji nema realne opozicije, stoga mu je za pregovore ostao kralj kao relevantan faktor.

Kad je 1933. u Zagreb stigao tajnik Liberalnog parlamentarnog kluba Richard Evans, imao je, kao i niz drugih inozemnih posjetitelja, mogućnost razgovora s Trumbićem. Domaćin mu je tom prilikom pokušao kritički objasniti epizodu stvaranja jugoslavenske države. Trumbić u svojoj reprodukciji bilježi sjećanja:

Bio je to neuspjeli eksperimenat, a poduzet je radi toga, što u ono vrijeme nisu mjerodavni državnici pravilno shvaćali hrvatsko pitanje. Sami Hrvati bili su pritisnuti o zid. Londonskim ugovorom bio im je ugrožen narodni obstanak, jer je postojala pogibelj, da će biti razderani u tri dijela: jedan dio imao je pripasti Austriji, drugi Italiji, a treći Srbiji. Da izbjegnu tomu cijepanju, ujedinili su se sa Srbijom u pretpostavci, da će biti jednakopravni sa Srbijancima. Srbija je u posebnom ugovoru preuzela svečanu obavezu, da će poštivati tradiciju i individualnost Hrvata. Ona je tu obvezu sustavno sve do danas gazila. Danas uvidjaju Hrvati, da je ovo stanje, u koje su upali poslije svršetka rata, za njih kud i kamo gore, nego li da se je proveo Londonski ugovor, jer bi ovako bila ugrožena njihova narodna zajednica, dok je danas u pitanju njihov narodni obstanak. ${ }^{46}$

Iz ove izjave britanski je političar mogao razumjeti da je Trumbić posve zabacio ideje narodnog jedinstva kao nezaživjelu formulu i da je, po njemu, najteži udarac jugoslavenskoj državi zadala srpska politička elita, odnosno jedna vrsta supremacije koja je onemogućila ravnopravnost naroda. Time se postavilo pitanje nove tranzicije države koja je još uvijek osjećala posljedice uvođenja diktature. Očita je bila nakana da se pri tome potaknu faktori odlučivanja u glavnim zapadnim zemljama, Velikoj Britaniji i Francuskoj, da izlože jugoslavensko vodstvo pritisku kako bi se preuredili unutarnji odnosi uz ravnopravnije zastupanje hrvatskih predstavnika s izbornim legitimitetom i tako izbjegnuli kobniji zapletaji.

44 O tome je Trumbić 1938. govorio nekadašnjem diplomatu i članu Demokratske stranke Miloju Milojeviću, objašnjavajući mu da je riječ o oportunistima koji su gledali samo svoje interese. Arhiv HAZU, fond A. Trumbić, bilješka od 25.6. 1938.

45 Arhiv HAZU, fond A. Trumbić, bilješka od 8. 12. 1932.

46 Arhiv HAZU, fond JO, sign. 126/16. 
Nakon Trumbićeve smrti mnogi su izražavali svoje mišljenje o njemu, izazivajući na određen način i polemike oko ocjene njegova političkog djelovanja. Dio hrvatskog nacionalističkog pokreta započeo ga je svojatati za svoje ideološke ciljeve. Zaobilazeći njegove prinose promicanju jugoslavenske ideje i ostvarivanju jugoslavenske države, proglasili su ga primjerom borca za hrvatsku nezavisnost, što je prije svega bio aktualan odraz napada na autoritet Vlatka Mačeka i potrebe da se uz nacionalistički pokret veže markantnu političku ličnost za čije se ime znalo i na međunarodnoj sceni. Neki od njegovih starih, ali i bivših suboraca za jugoslavensku stvar pokušavali su pronaći uravnoteženiju ocjenu i s nelagodom bilježili odbacivanje nekadašnjih ideala. Opravdavali su njegovu razočaranost, ali su istodobno smatrali da se u svojoj kasnijoj dobi više nije najbolje snalazio u javnom životu. Tako će ga doživjeti Josip Smodlaka, suputnik iz splitskih dana i suradnik s mirovne konferencije u Parizu, zapisavši da se Trumbić smrću „vraća na mjesto koje mu pripada u historiji, mjesto prvoborca za hrvatska prava i borca za Jugoslaviju. ${ }^{\text {“47 }}$ Milan Ćurčin priznao je da se Trumbić, kao nekadašnji sudionik pokretanja časopisa Nova Evropa, odvojio od hrvatsko-srpske linije i prišao pokretu „obnove hrvatstva“, ali je istaknuo da historičari neće moći mimoći činjenicu da je on bio „u najkritičnije doba za ceo narod, a u svoje najbolje i najaktivnije godine i dane, - i dobar sin i prvobranitelj Jugoslavije. "48 $S$ druge strane, i za Miroslava Spalajkovića, jednog od iskusnijih diplomata s kojime je Trumbić nekada bio u kontaktu, beogradske su novine objektivno opisale pokojnikov opus, zabilježivši „njegove zasluge kao

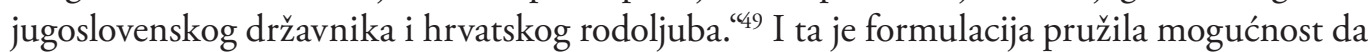
se Trumbiću odredi dolično mjesto u kulturi pamćenja, ali i da se ostavi prostor za suradnju između predstavnika dvaju naroda za koje se smatralo da su težište jugoslavenske države. Konačno, važno je zabilježiti i nešto kasnije mišljenje Milana Grola iz ratne emigracije. Taj nekadašnji Trumbićev sugovornik iz vremena Prvoga svjetskog rata i međuraća dao je neke odgovore na vidnu razočaranost nekadašnjeg prvaka Jugoslavenskog odbora s iskustvima u jugoslavenskoj državi. Grol piše: „Pre a posle, Trumbić je morao podleći, ali nikad ne bi bio srušen potpuno da je bio nešto priznat i respektovan u Beogradu. Nepravda s te strane, otrovala je njegova osećanja. “50 U pozadini je, prema Grolu, ležao obračun tadašnjih prvaka u kraljevoj Vladi koji Trumbiću nisu htjeli oprostiti protivljenje Vidovdanskom ustavu.

Kolikogod je razočaranje političkom situacijom bilo duboko, za Trumbića ono nije značilo i potpuno zabacivanje pokušaja suradnje između predstavnika Hrvata i Srba. Drugim riječima, on je i dalje primao obavijesti o odnosima u Beogradu od raznih izaslanika i posrednika, sagledavajući ih u skladu s njegovim pesimističkim pogledima na situaciju u Jugoslaviji. Najviše podataka donosio mu je stari prijatelj Ivan Meštrović, koji je često boravio u Beogradu i odande mu prenosio poruke pojedinih utjecajnih ljudi te informacije o aktualnim kombinacijama ili mu, pak, iznosio dojmove o raznim zbivanjima kao bitnim smjernicama u državi. Trumbićeve političke bilješke, u kojima se često raspredalo bez uvijanja o raznim pitanjima, pokazuju da je neprestano bio duboko razočaran režimom i

\footnotetext{
47 J. Smodlaka, „Ante Trumbić“, Nova riječ (Zagreb), br. 102, 1938., 7.

48 M. ĆurČIn, „Smrt Dra. A. Trumbića“, Nova Evropa (Zagreb), br. 11, 1939., 382-383.

49 M. Spalajković, „Uspomene na A. Trumbića“, Pravda (Beograd), br. 12268-12271, 6. 1. 1939., 2.

50 Milan Grol, Londonski dnevnik 1941-1945, Beograd 1990., 483.
} 
njegovim pogrešnim smjerom. Otklon od njega pokazivao je u zagovaranju programme de combat do maksimuma. ${ }^{51} \mathrm{No}$, istodobno je, unatoč sklonosti prema zauzimanju odrješitijih stajališta, izražavao zabrinutost za budućnost, strahovao od izbijanja rata zbog sve zaoštrenijih odnosa na međunarodnim obzorima, a nije krio ni bojazan od revolucije kojom bi se otvorila vrata komunističkim idejama. Izlaz je iz vrtloga vidio u bezodvlačnom dogovoru legitimnih predstavnika Beograda i Zagreba, očito i dalje polazeći od tvrdnje da su središta Srba i Hrvata ključna za održivost države.

\section{$\cos$}

\section{Ante Trumbićs approaches to The YugoslaV Question AND BELGRADE}

The speaker analyses the circumstances and motives behind Ante Trumbićs changing views of the Yugoslav question, drawing from his research of the political notes found on Trumbićs Zagreb estate. It is certain that Trumbić supported a break with Austria-Hungary and a merger with the Kingdoms of Serbia and Montenegro, both immediately before World War I (in Split) and during the war (in emigration). In fact, he may be regarded as one of the forefathers of the first Yugoslav state, who insisted that the country should bear the Yugoslav name from the very beginning. The paper points out that Trumbić made efforts towards extensive cooperation with Serbian delegates and systematically insisted on the shared values of all South-Slavic nations. After Trumbić left the position of the Minister of Foreign Affairs, which had been caused largely by the way the Adriatic question was treated in diplomacy and the clashing of the views regarding the adoption of the Vidovdan Constitution, and, most of all, after his relocation to Zagreb, there occurred a shift in his views on the country's system of politics, the Yugoslav identity and the powers that be. Some historians interpreted this as Trumbićs return to the ideology of the Party of Right, or perhaps a sign that he began embracing the idea of the confederalization of Yugoslavia, although it is quite clear that his growing dissatisfaction with the situation in the Kingdom of Serbs, Croats and Slovenes (culminating with the establishment of the dictatorship and the stifling of the opposition) ran much deeper. In this sense, Trumbić did begin detaching himself from Belgrade, yet showing no nostalgia for the Party of Right. At the same time, archival records show that he continued to correspond with certain figures from the public sector in Belgrade, discussing the situation in the country. With this in mind, the author claims that Trumbićs attitudes towards the Yugoslav question reflected the political climate of the time.

Key words: the Yugoslav question, the Yugoslav identity, the Yugoslav Committee, Croatian-Serb relations 


\section{$\cos$}

\section{Izvori}

Arhiv Hrvatske akademije znanosti i umjetnosti, fond Ante Trumbića, Zagreb

Arhiv Hrvatske akademije znanosti i umjetnosti, fond Jugoslavenskog odbora, Zagreb

Arhiv Hrvatske akademije znanosti i umjetnosti (dalje: Arhiv HAZU), fond Jugoslavenskog odbora (dalje: fond JO), Zaklada Jugoslavenskog odbora, bez sign.

Arhiv HAZU, fond A. Trumbić

\section{Literatura}

Lujo BАкотіć, „Dr. Ante Trumbić, Država (Split), 18. 12. 1924., 1.

Ljubo Boвan, „Prilozi za biografiju Ante Trumbića u vrijeme šestojanuarskog režima, 1929-1935“, Historijski zbornik, 21-22/1968. - 1969., 1-73.

Marijan Buljan, „Uroš Desnica i Narodna radikalna stranka u Splitu 1920-ih prema splitskoj periodici“, Vladan Desnica i Split 1920.-1945. Zbornik radovas Desničinih susreta 2014. (ur. Drago Roksandić i Ivana Cvijović Javorina), Zagreb 2015., 285-306.

M. Ćurčın, „Smrt Dra. A. Trumbića“, Nova Evropa (Zagreb), br. 11, 1939., 382-383.

Dejan Djokić, Nikola Pašić and Ante Trumbić. The Kingdom of Serbs, Croats and Slovenes, London 2010.

Dr. Ante Trumbić (1864. - 1938.). Životopis kroz spise osobnoga Arhiva u Sveučilišnoj knjižnici u Splitu (prir. Mihaela Kovačić i Marko Trogrlić), Split 2015.

„Dr. Ante Trumbić o Krfskoj deklaraciji“, Hrvatska riječ (Split), br. 184, 1924., 3.

Tereza Ganza-Aras, Politika „novog kursa“ dalmatinskih pravaša oko Supila i Trumbića, Split 1992.

Milan Grol, Londonski dnevnik 1941-1945, Beograd 1990.

Dragoslav Janković, „Ante Trumbić na Krfskoj konferenciji“, Život i djelo Ante Trumbića (ur. Ljubo Boban i Ivan Jelić), Zagreb 1991., 61-66.

Dragoljub Jovanović, Ljudi, ljudi, knj. II, Beograd 1975.

Miroslav KRlEžA, Marginalije (prir. Vlaho Bogišić), Beograd 2011.

Božidar Marković, „Prvi koraci ka narodnom sporazumu“, Spomenica Ljubomira Davidovića, Beograd 1940., 54-62.

Stjepan Matković, „Milan Ćurčin, Južnoslavensko pitanje u Prvome svjetskom ratu i rasprave o Sarajevskom atentatu“, Istorijski zapisi, 87/2014., br. 3-4, 115-133.

„Narode!“, Novo doba (Split), br. 149, 5. 11. 1918., 1.

Nova Evropa 1920-1941 (ur. Marko Nedić i Vesna Matović), Beograd 2010.

Ivo Perić, Ante Trumbić na dalmatinskom političkom poprištu, Split 1984.

Ivo Petrinović, Ante Trumbić. Politička shvaćanja i djelovanja, Zagreb 1986.

„Prilike u našoj diplomatskoj službi. Nedovoljno učešće Hrvata i Slovenaca“, Novo doba (Split), br. 298, 1927., 2.

Drago RoksAndić, „Dr. Uroš Desnica 1918.-1921.: životopisne nedoumice na raskrižju epohâ“, Spalatumque dedit ortum. Zbornik povodom desete godišnjice Odsjeka za povijest Filozofskog fakulteta u Splitu (ur. Ivan Basić i Marko Rimac), Split 2014., 499-511. 
Drago RoKsandić, Srpska i hrvatska povijest i „nova historija“, Zagreb 1991.

Ante Smith Pavelić, Dr. Ante Trumbić, problemi hrvatsko-srpskih odnosa, München 1959.

J. Smodlaka, „Ante Trumbic“", Nova riječ (Zagreb), br. 102, 1938., 7.

M. Spalajković, „Uspomene na A. Trumbića“, Pravda (Beograd), br. 12268-12271, 6. 1. 1939., 2.

Đorđe Stanković, Nikola Pašić i Hrvati (1918-1923), Beograd 1995.

Đorđe Stanković, Srbija i stvaranje Jugoslavije, Beograd 2009.

Nikola Stojanović, Mladost jednog pokolenja (uspomene 1880-1920) (prir. Mile Stanić), Beograd 2015.

Dragovan Šeprć, Italija, Saveznici i jugoslavensko pitanje, Zagreb 1970.

„Trumbićev 'dnevnik'“, Historijski pregled (Zagreb), 1959., br. 2, 165-189.

Radoslav Vesnić mLaĐi, Dr Milenko Vesnić gransenjer srpske diplomatije, Beograd 2008.

Zapisi Dra Josipa Smodlake (ur. Marko Kostrenčić), Zagreb 1972. 